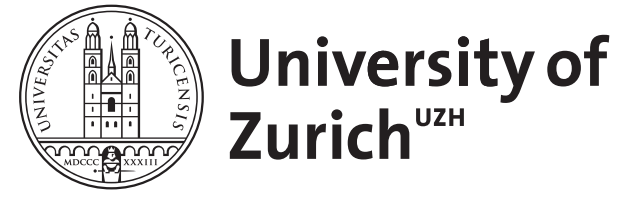

\title{
Migration in far West Nepal
}

Poertner, E ; Junginger, M ; Müller-Böker, U

DOI: https://doi.org/10.1080/14672715.2011.537850

Posted at the Zurich Open Repository and Archive, University of Zurich ZORA URL: https://doi.org/10.5167/uzh-48008

Journal Article

Accepted Version

Originally published at:

Poertner, E; Junginger, M; Müller-Böker, U (2011). Migration in far West Nepal. Critical Asian Studies, $43(1): 23-47$.

DOI: https://doi.org/10.1080/14672715.2011.537850 


\title{
Intergenerational linkages between internal and international migration of rural-to-urban migrants in Far West Nepal
}

\author{
Ephraim Poertner, Mathias Junginger, Ulrike Mueller-Boeker
}

\begin{abstract}
In Nepal, international labor migration to India and overseas as well as internal migration to the rural Nepalese lowlands are of a high socio-economic significance. Scholarly debates about migration in Nepal have gradually shifted from an economic to a more holistic perspective, also incorporating social dimensions. However, little evidence has been generated about internal migration to urban destinations and the potential linkages between international and internal migration. This article draws on Bourdieu's Theory of Practice and sees migration as a social practice. Accordingly, migration practice is regarded as a strategy applied by social agents to increase or transfer capitals and ultimately secure or improve their social position. The evidence is based on a qualitative case study of rural-to-urban migrants in Far West Nepal conducted in July and August 2009. The study at hand addresses linkages between internal and international migration practices and provides insight about a social stratum that is often neglected in migration research: the middle class and more precisely, government employees. We show that social relations are crucial for channeling internal migration to a specific destination. We furthermore unveil how internal migration is connected to the international labor migration of former generations. Finally, we examine how migration strategies adopted over generations create multi-local social networks rooted in the family's place of origin.
\end{abstract}

\section{Introduction}

It all started with the phone book. Sitting on the shady veranda in front of Dhan Bahadur's house, we are gasping for cool air, trying to cope with the tremendous heat and humidity of the late Terai summer. Dhan's wife, who migrated with him and their three children from Bajhang district to Dhangadhi a couple of years ago, tells us to wait outside. Fifteen minutes later, her husband comes into the courtyard, wearing smart trousers and a white long-sleeved shirt. He takes a seat, orders a cup of tea and asks about the reason for our visit. Shortly after we have outlined our research project, he instructs his wife to go inside and look for the phone book... Surprisingly, the little paperback does not primarily contain phone numbers but rather lists the names and places of origin of those who own property or have settled at a place everybody calls Babjangi Tole. It turns out to be a promising document for insights into the field of internal migration research.

In Nepal, international labor migration and internal migration from the mountain and hill regions to the lowlands are long-standing and of high socio-economic significance. Since an open border agreement was established between Nepal and India in 1950, international migration to India for work has become a livelihood strategy pursued by a large part of Nepal's rural population in hill and mountain regions. Accordingly, remittances from labor migration have constituted a crucial source of income for the households in these regions, where people's livelihoods are primarily based on subsistence agriculture. According to estimates, more than a million Nepalese are currently working in India. ${ }^{1}$ Internal migration to the Nepalese lowland, the Terai, was stimulated by government resettlement schemes after successful malaria eradication programs in the 1950s. These schemes aimed to increase agricultural production and to provide land for landless and flood-affected hill people in the then sparsely populated and densely forested Terai. An unexpected and unplanned squatter colonization accompanied the resettlement schemes. Households migrated to the rural Terai to cope with the lack of opportunities to make a living in the hills or to improve their livelihoods through farming fertile land in the lowlands. ${ }^{2}$ In recent decades, people have started to migrate to the emerging urban areas of the Terai for employment and education. Within fifty years, migratory movements have shifted the population centre from the hills to the lowlands, where the majority of Nepal's population now lives. ${ }^{3}$

\footnotetext{
${ }^{1}$ Kollmair et al. 2006; Sharma 2007; Thieme 2006.

${ }^{2}$ Shrestha 1990.

${ }^{3}$ KC 2003.
} 
Migration in Nepal has been an increasingly frequent topic of research in the last two decades. Scholars have paid particular attention to international labor migration to India ${ }^{4}$ and the remittances generated through international labor migration ${ }^{5}$. Research into internal migration has focused mainly on rural-to-rural migration, namely resettlement schemes and migration from the hills and mountains to the rural Terai ${ }^{6}$ and internal displacement induced by the recent Maoist conflict ${ }^{7}$. Despite the strong urbanization trend in Nepal, rural-to-urban migration has been generally neglected in migration research, except in a few noteworthy studies by Graner, Luitel, and Timalsina. ${ }^{8}$ Likewise, only a few scholars have considered both internal and international migration ${ }^{9}$, although the two types of migration are likely to be interlinked in many $\operatorname{cases}^{10}$. Linkages between internal and international migration in Nepal have been rarely researched to date. Graner has shown that migrants who moved from rural areas of Nepal to Kathmandu for work later migrated abroad with manpower agencies in search of better-paid jobs. ${ }^{11}$ Furthermore, various authors ${ }^{12}$ have suggested that quite a number of international migrants from Far Western Nepal also migrated internally.

This article aims to elucidate and corroborate evidence of internal migration and its interlinkages with international labor migration. It focuses on rural-to-urban migration from the hills to the Terai. The emphasis is on the spatiality of migration practices and the significance of social networks.

Map 1: Nepal: source and destination districts

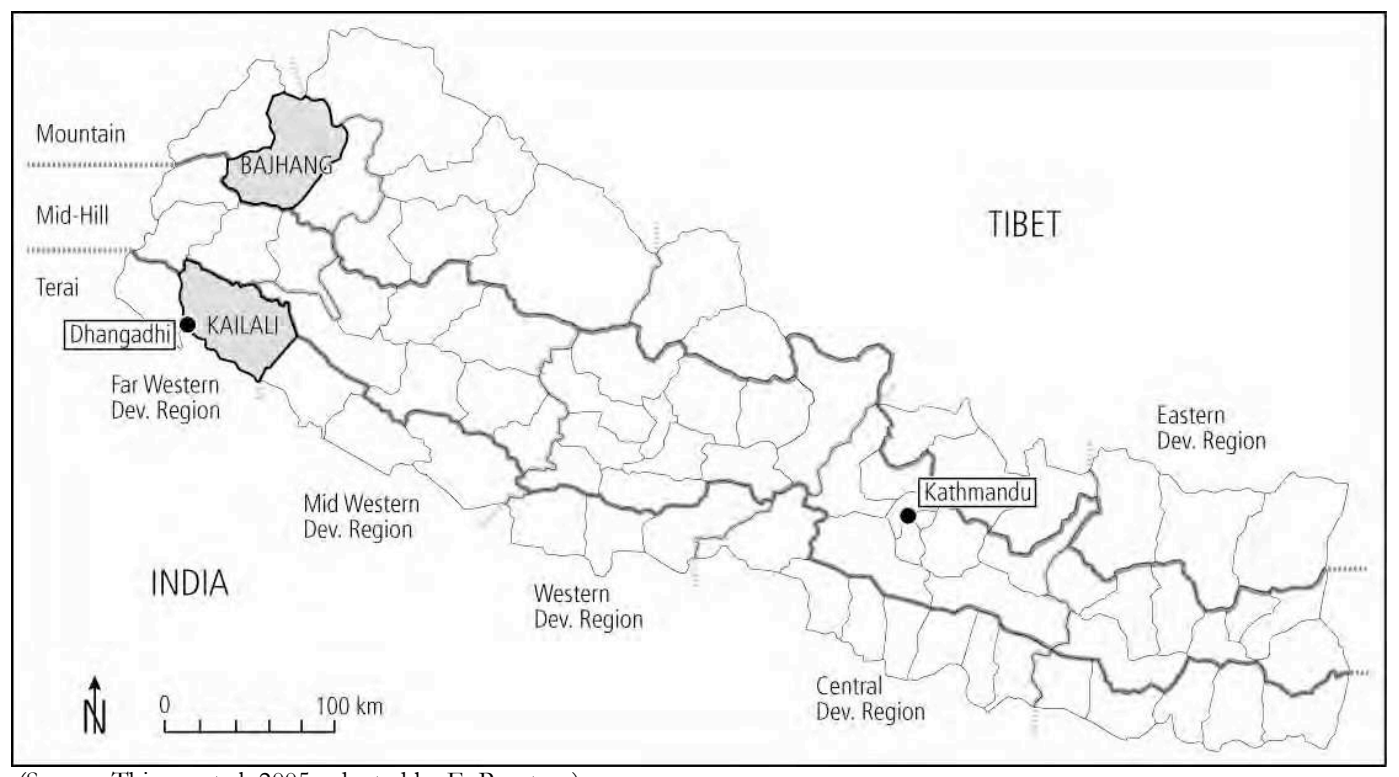

(Source: Thieme et al. 2005, adapted by E. Poertner)

The discussion in this article is based on the results of research on internal migration from Bajhang District to the municipality of Dhangadhi in Kailali District in Far West Terai (see map 1). In the remote mountainous Bajhang, there have only been a few studies that have highlighted the significance of international labor migration as a livelihood strategy. ${ }^{13}$ A case study about migration and societal change in Bajhang is currently being conducted by the Development Study Group Zurich. While there has been some research into the international destinations of migrants from Bajhang such as Delhi

\footnotetext{
4 Adhikari and Gurung 2009; Bhattrai 2007; Bruslé 2008; Kansakar 2003; Kaspar 2004; Müller-Böker 2003; Müller-Böker and Thieme 2007; Pfaff-Czarnecka 1996; Shahi 2005; Sharma 2007; Subedi 1991; Thieme 2006; Thieme et al. 2005; Thieme, MüllerBöker, and Backhaus Forthcoming; Upreti 2002.

${ }^{5}$ Kollmair et al. 2006; Seddon, Adhikari, and Gurung 2002; Shrestha 2008; Wyss 2003.

${ }^{6}$ Agergaard 1999b, 1999a; Müller-Böker 1997, 1999, 2000, 2001; Shrestha 1989, 1990; Thapa 1989.

7 Bhattarai-Ghimire and Upreti 2008; Tamang 2009; Ghimire, Upreti, and Pokharel 2010.

${ }^{8}$ Graner 2001; Luitel 2006; Timalsina 2007.

${ }_{9}^{9}$ Bohra and Massey 2009; Dahal, Rai, and Manzardo 1977; Subedi 1993.

10 See Skeldon 2006.

11 Graner 2001

12 Bruslé 2008; Pfaff-Czarnecka 2001; Shahi 2005; Thieme 2006; Thieme, Müller-Böker, and Backhaus Forthcoming.

${ }^{13}$ Cameron 1998; Müller-Böker 2003; Müller-Böker and Thieme 2007; Pfaff-Czarnecka 1989, 2001; Shahi 2005.
} 
and Bangalore, ${ }^{14}$ empirical studies of internal destinations are lacking yet. This qualitative case study was therefore carried out at an internal destination, a ward of Dhangadhi, from July to August 2009.

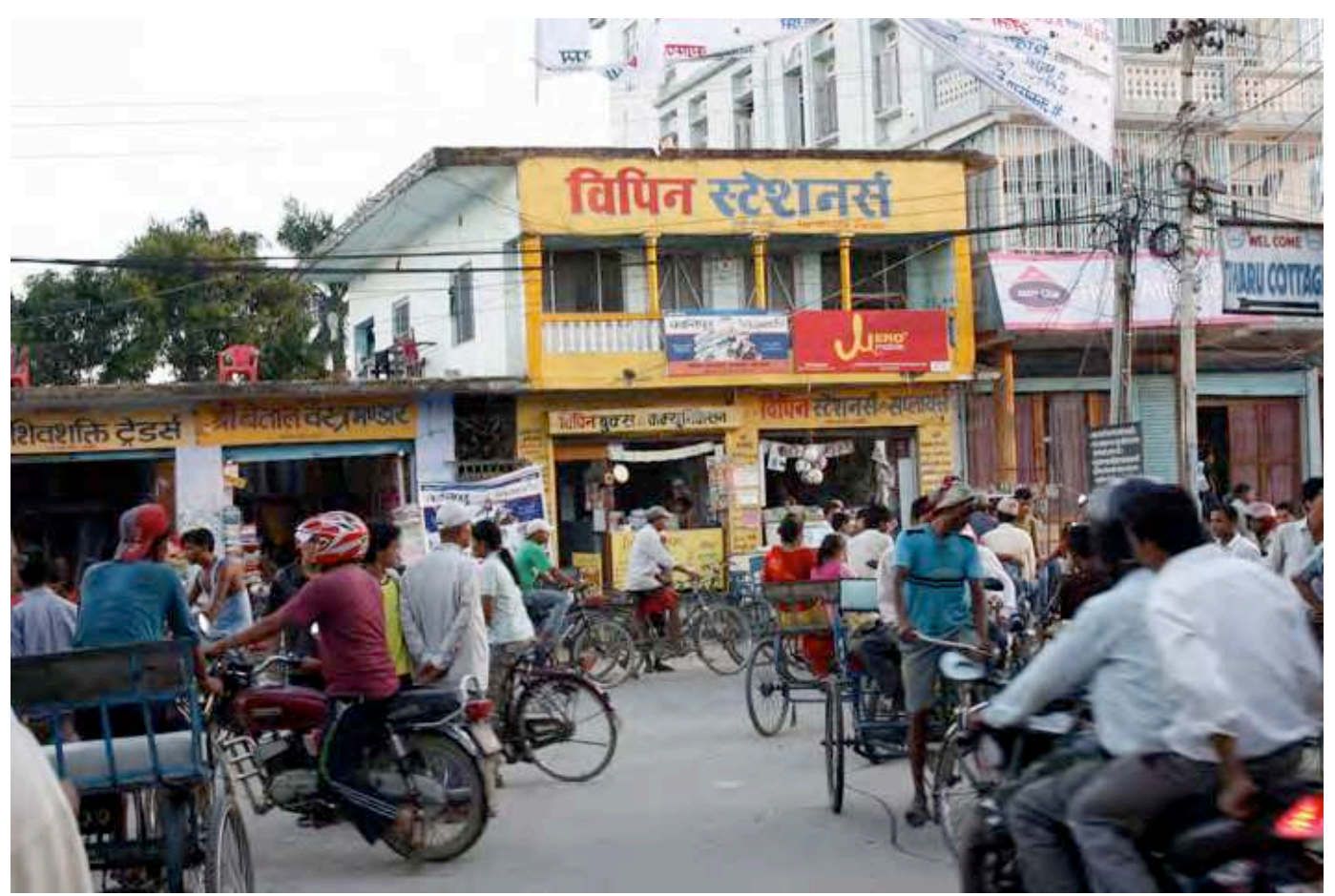

The busy Bazaar Road in the city centre of Dhangadhi. Compared to the places of origin, the far western hills, the municipality in Kailali district provides a diverse range of goods and public services. (Image: E. Poertner)

This article draws on an analysis of semi-structured interviews with members of 35 migrant households. In these interviews, the focus was on their migration trajectories and history, as well as their social networks. The households were selected with the help of the aforementioned telephone directory containing the names of migrants from Bajhang and a wealth ranking of the total 88 households in the study location. ${ }^{15}$ The household sample comprised the differences in relative wealth and caste/ethnic group affiliation. Narrative interviews concerning the migration history of nine selected households, a focus group discussion and participatory methods complemented the empirical data collection. Interviews with key figures - such as the chairman of the association of immigrants from Bajhang in Dhangadhi - as well as migration and minority experts broadened the picture and helped to contextualize the data collected.

We first introduce the conceptual framework of the article using Bourdieu's Theory of Practice. Secondly, we present a picture of the migrant households and the community at the urban destination in terms of caste, class, gender, labor and education. Thirdly, we examine the migration trajectories and motives of the households and commuting practices related to work. Fourthly, we disclose linkages of the internal migration to international labor migration to India; and finally, we discuss social relations to different places, their maintenance and significance.

\section{Conceptual framework: migration as social practice}

Until now, migration has not been approached using a shared paradigm "but from a variety of competing theoretical viewpoints fragmented across disciplines, regions, and ideologies". ${ }^{16}$ A fundamental disciplinary cleft has been identified between macro-level perspectives and a focus on market forces or immigrant policies, and micro-level perspectives emphasizing individual experiences or household strategies. ${ }^{17}$ On this account, different authors ${ }^{18}$ have suggested to understand migration as social practice and thus to apply Bourdieu's Theory of Practice ${ }^{19}$.

\footnotetext{
14 Pfaff-Czarnecka 1996; Thieme 2006.

${ }^{15}$ See Grandin 1988.

${ }^{16}$ Massey et al. 1994, 700.

${ }^{17}$ Brettell and Hollifield 2007, 2.
} 
The Theory of Practice attempts to resolve the sociological dualism between society and subject, between structure and agency, by adopting a relational perspective. ${ }^{20}$ Its aim is to grasp social practice and the inherent logic of such practice in the dialectic relation of habitus and social field. ${ }^{21}$

"A field consists of a set of objective, historical relations between positions anchored in certain forms of power (or capital), while habitus consists of a set of historical relations 'deposited' within individual bodies in the form of mental and corporeal schemata of perception, appreciation, and action." 22

Social agents are endowed with systematically structured dispositions, a habitus, which is constitutive of their practice and their reflection about practice. The habitus is socially and historically shaped through the incorporation of individual and collective experiences. ${ }^{23}$ Social fields are external, objective structures that are complementary to the internal structures of the habitus and constituted through social practices. ${ }^{24}$ Social agents draw upon a form of repertoire of time-tested practices and strategies, which make their actions relatively independent of the short-term influences of the present. ${ }^{25}$ Social agents are endowed with, and struggle for, different types of capitals, resources that are more or less valuable in a specific social field. Bourdieu distinguished between four fundamental types of capital, economic, cultural, social, and symbolic capital, which are all transformable into one another. ${ }^{26}$ Economic capital refers to different forms of tangible property that are usually transferable into currency. Cultural capital exists in three forms: as materialized cultural objects, as cultural abilities, skills and forms of knowledge incorporated in the habitus, and as institutionalized education qualifications, the most valuable form. Social capital refers to the resources resulting from membership of a social group (family, club, political party etc). Symbolic capital is the perceived form of other capitals, which is recognized as legitimate and commonly called 'prestige' or 'renown'.27 Capitals determine the opportunities of social agents, their action and success within a social field ${ }^{28}$.

How can the Theory of Practice be adapted to the field of geography and to migration research? It is particularly suitable for analyzing internal power hierarchies in different social fields, such as communities or households. But with its emphasis on social practices and their historical depth, the spatial aspects of such practices tend to be neglected. ${ }^{29}$ However, Bourdieu highlighted that spatial practices the arrangement of agents and features in physical space - tend to be a manifestation of social space. ${ }^{30}$ He argues that the locations occupied by agents and their places in geographical space are excellent indicators of their positions in social space. Many spaces have a 'barrier to entry', for instance a museum, or - for someone from a low caste - a high caste house. But similar barriers also exist in medical and legal facilities, and in most educational institutions. Beyond spaces that require economic and cultural capital, certain spaces - particularly 'exclusive ones' - call for social capital. In turn, for those who have access to them, such spaces provide social and symbolic capital - a circumstance that Bourdieu calls the 'club effect'. ${ }^{31}$

'Migration is ... bound up with contests and negotiations over one's place in society. (...). Moreover, migrants make use of social resources and networks - who they know - to access or avoid particular types of work and/ or migration destinations." 32

We argue that both the migration decisions and the destinations of social agents are conditioned by their social, human and economic capital, and furthermore that migration changes how these capitals are valued and can be transferred. The cultural capital of migrants is re-evaluated at the migration destination. Actually, for international migrants, this often means a devaluation of their institutionalized cultural capital if their educational qualifications are not recognized in the new national context, i.e.

\footnotetext{
${ }^{18}$ De Haan and Zoomers 2005; Dörfler, Graefe, and Müller-Mahn 2003; Herzig and Thieme 2007; Thieme $2006,2008$.

${ }^{19}$ Bourdieu 1977.

${ }^{20}$ Bourdieu and Wacquant 1992, 15-16.

${ }_{21}$ Dörfler, Graefe, and Müller-Mahn 2003, 15.

22 Bourdieu and Wacquant 1992, 16.

${ }^{23}$ Schwingel 1995, 61-62.

${ }^{24}$ Schwingel 1995, 76.

${ }_{25}$ Dörfler, Graefe, and Müller-Mahn 2003, 18.

${ }^{26}$ Bourdieu and Wacquant 1992.

${ }^{27}$ Schwingel 1995, 88-93.

${ }^{28}$ Schwingel 1995, 83-85.

${ }_{29}$ Thrift 1996, 15.

${ }^{30}$ Bourdieu 1991.

31 Bourdieu 1991, 34.

${ }^{32}$ De Haan and Rogaly 2002, 9.
} 
not considered legitimate. In the case of rural-to-urban migrants, agricultural knowledge is hardly valued at the urban destination, despite it being essential in their rural place of origin. Instead, knowledge about the urban labor markets and legal obligations and rights becomes crucial. ${ }^{33}$ Social capital is created through the maintenance of social networks with specific destinations, in the event of labor migration from Nepal to Indian cities such as Delhi or Bangalore. At these destinations, access to the fields of labor (for Nepalis, particularly to the field of watchmen) is highly dependent on social capital, as the jobs are usually passed on or sold to relatives or fellow villagers. ${ }^{34}$ The successful migrant's symbolic capital increases back home. Sending remittances, investing in land, housing or their children's education, or bringing gifts increases the migrants' prestige locally and enhances the social position of his household. ${ }^{35}$

\section{Establishing the community field: Bajhangi Tole}

After successful malaria eradication in the 1950s, Kailali District and later the city of Dhangadhi became popular destinations for migrants from the adjoining hill districts. Dhangadhi municipality experienced remarkable population growth from the 1980s onwards and is still one of the fastest growing municipalities of Nepal. ${ }^{36}$ Approximately 75,000 people are currently living in more than 12,000 households in the municipality. ${ }^{37}$ Shivanagar is a municipality ward close to the centre of Dhangadhi (see map 2).

Map 2: Central Dhangadhi, Bajhangi Tole

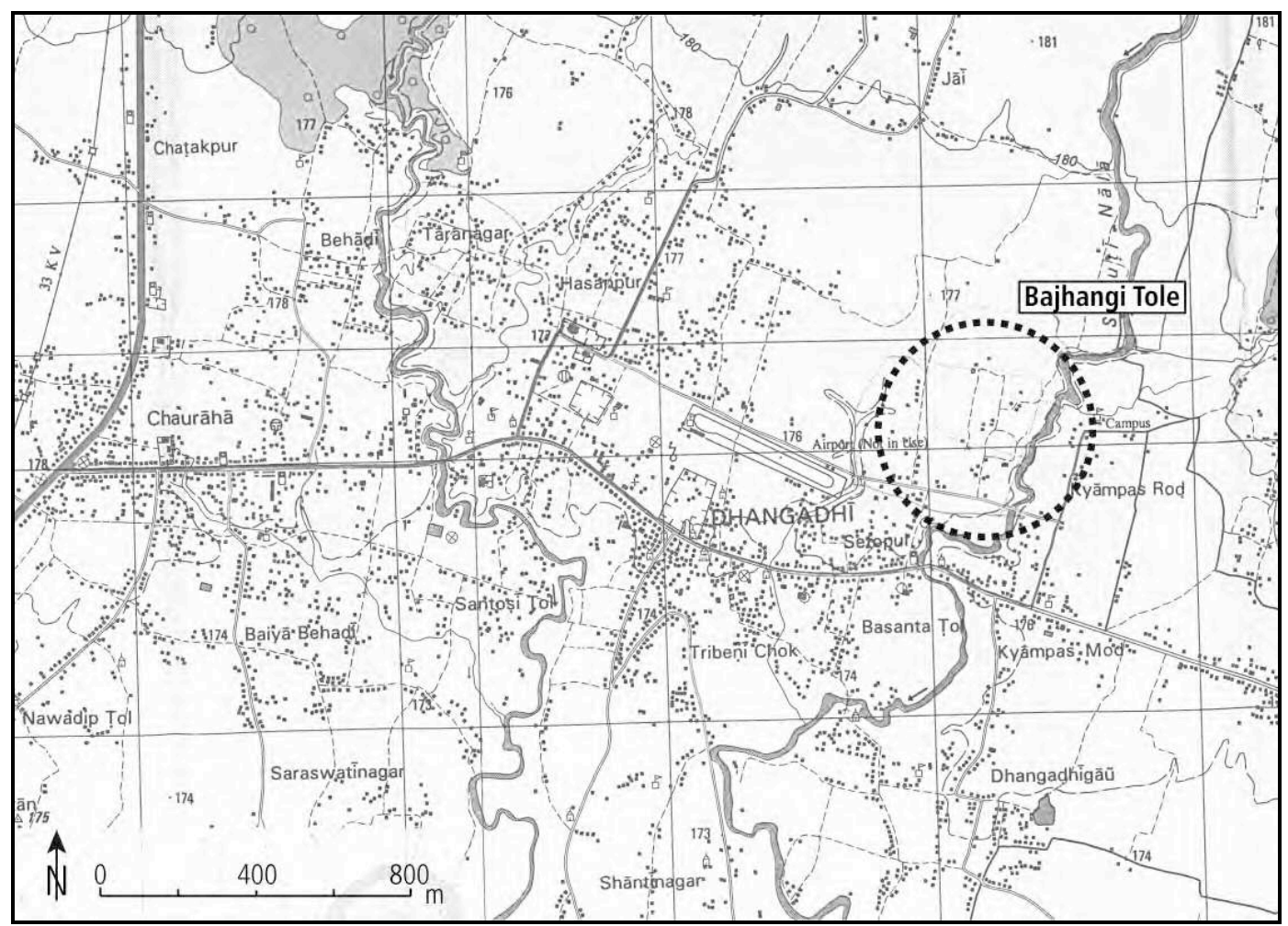

(Source: HMG 1998, adapted by E. Poertner)

However, the term 'municipality ward' might create a misleading urban impression of the settlement; it is comprised of one- and two-storey houses that are loosely scattered and grouped around a large plain area, with paddies and garden yards between them. Simple, thatched, clay-coated houses are dispersed around the neighborhood; these are the traditional dwellings of the indigenous Tharu. Within Shivanagar, one quarter is called 'Bajhangi Tole', which literally means 'place of the people from Bajhang', since migrants from this district concentrate here. This tole hosts almost a hundred households

${ }^{33}$ Herzig and Thieme 2007, 1097.

34 Thieme 2008, 60.

${ }^{35}$ Herzig and Thieme 2007, 1096.

36 Sharma 2003, 381.

${ }^{37}$ Dhangadhi Municipality 2008. 
from Bajhang, as well as migrants from other hill districts such as Achham, Doti or Dadeldhura and indigenous Tharus. The community of Bajhangi Tole is quite homogeneous concerning caste affiliation. It is almost exclusively hill high-castes (Bahun, Thakuri and Chhetri) that settle in Bajhangi Tole, and only two out of 88 households are low-caste (so-called Dalits). The rationale behind this is, on the one hand, that social and economical discrimination against Dalits means they do not usually have enough economic and social capital to purchase land and build houses in a central urban area like Shivanagar; they settle on the edge of the city instead. On the other hand, as social networks play a crucial role in choosing a destination, a segregation effect of households belonging to the same caste can be observed.

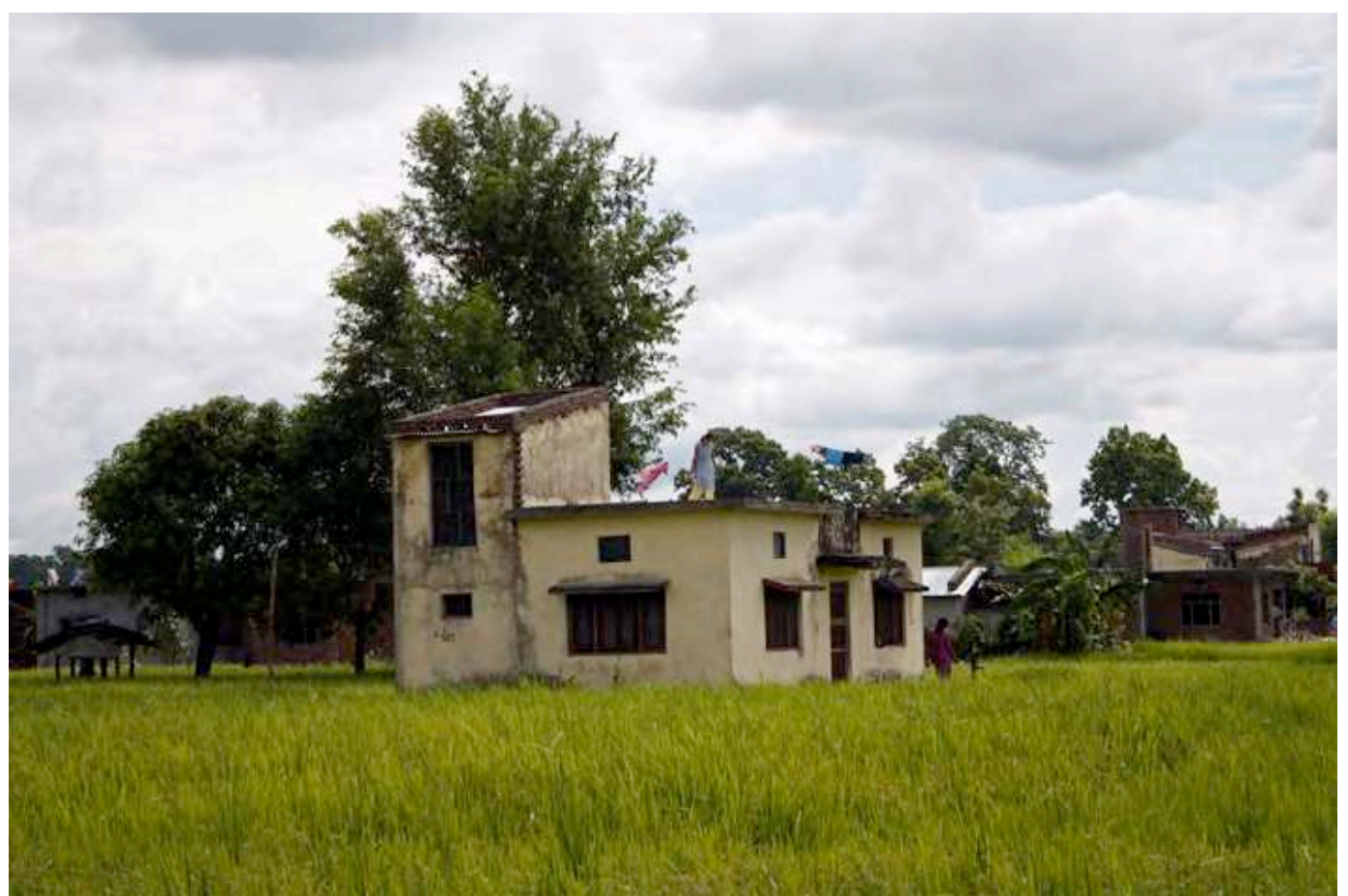

A typical one-storey building in the loosely scattered settlement of Shivanagar surrounded by paddy fields and kitchen gardens. (Image: E. Poertner)

The local conception of wealth points to three common indicators (valued forms of economic capital) in the social field of the internal migrants: housing, landholdings, and income. Land holdings in Shivanagar are generally rather small (between 1 and $2 k a t t h a^{38}$ ), and they are mainly used for housing. But quite a few people own larger plots ( 5 to 40 kattha) of agricultural land outside central Dhangadhi in the rural Terai. These plots are mostly cultivated by tenants under adbiya ${ }^{39}$ (sharecropping) arrangements. Land ownership by urban settlers in rural areas represents an investment that increases their social position as well as reduces their expenditure on food. More than four-fifths of the households in Bajhangi Tole still own land in their village of origin (up to 80 kattha), and this is usually cultivated by relatives. Along with this land, the ghar (ancestral home of the husband) of most households is still located in their village of origin. The great importance attributed to land, even when they have migrated to an urban area, indicates that land ownership is key to welfare and status in Nepal, over and above the role it plays in subsistence in rural areas. ${ }^{40}$ The particular emphasis on labor as a 'source' of (new) wealth and financial capital for investment stems from the high proportion of people with jobs in Shivanagar and the significance of work for urban livelihoods. Although those who have settled in Bajhangi Tole emphasized the generally middle-class status of the community, there are nevertheless considerable disparities in residents' wealth.

Most households derive a regular income from their husbands being in salaried employment as teachers or government officials. Many of these teachers or government officials still work in the hills, de-

\footnotetext{
381 kattha $=339 \mathrm{~m}^{2}$.

39 Adhiya refers to the practice of giving land under tenancy, whereupon the rent is not paid in money but as half of the crop yield.

${ }^{40}$ Cf. Agergaard 1999a.
} 
spite having relocated their household. They therefore travel back and forth between Bajhangi Tole and the hills on a quarter- to half-yearly basis (see fig. 1).

"[Usually] I work for about two and a balf months in Achbam and then return to Shivanagar for two to four days. I used to work in the land reform office in Dhangadhi for nine years. The stations ${ }^{41}$ before that were the veterinary office in Bajhang and civil service in Baitadi and in Kalikot. I have worked in the civil service for almost 20 years." (Man, 40 years old, Dhangadhi, 23 August 2009)

Besides such government employees, there are a few contractors and private employees as well as labor migrants to India or overseas living in the settlement. Women are in general very rarely engaged in employment outside the household. Correspondingly, the education background of the parental generation is highly gendered: men have quite a high level of formal education (more than four-fifths have at least a School Leaving Certificate, every fourth man even has a Bachelor's or Master's degree). In contrast, about half of the women are illiterate. However, the educational situation of the children's generation looks promising: girls and boys alike are enrolled in private schools and attend school until at least higher secondary level. There is still a gender difference for higher education (Bachelor's and Master's level): the daughters study in Dhangadhi, while the sons often have the chance to study in Kathmandu.

Fig. 1: Common migration practices

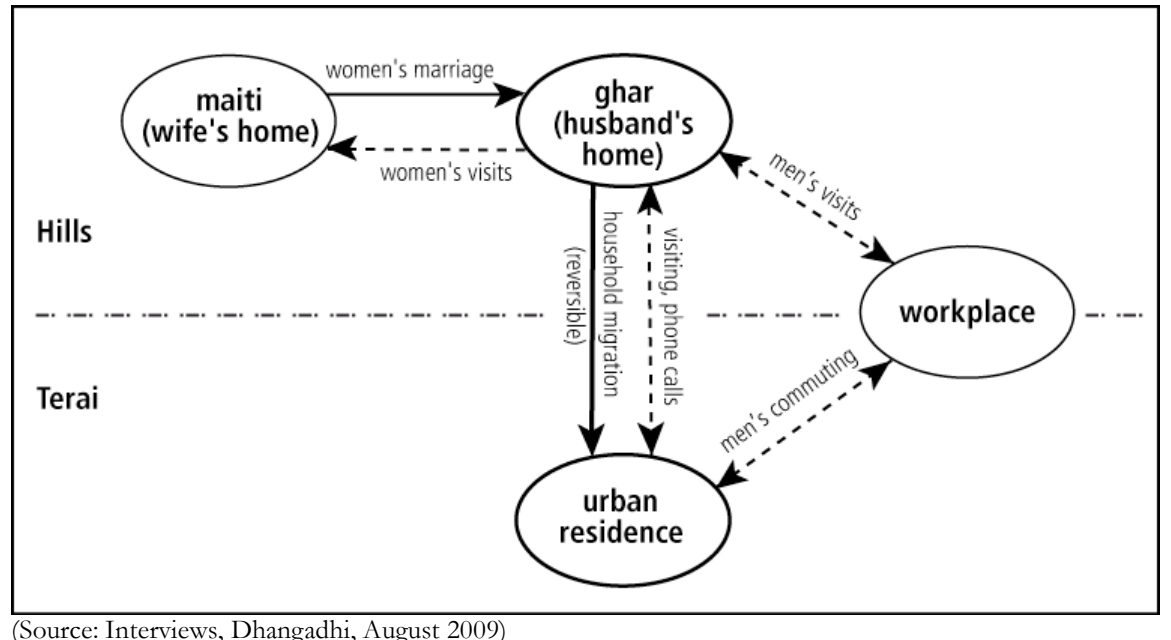

Household composition in Bajhangi Tole often deviates from the 'ideal Hindu joint family', ${ }^{42}$ which is characterized as "an extended household, comprising two or more generations of a patri-local family, with the oldest active male as the household head". According to Agergaard, households are divided into various nuclear or sub-households due to staggered phases of transition, but also due to the migration of parts of the family. ${ }^{43}$ In Bajhangi Tole, the relocation of households and (long-term) commuting for work by men have created such nuclear and sub-household forms consisting of both sedentary and mobile household members. Therefore, female-headed households exist alongside traditional extended households. (Female-headed refers to wives being de facto household heads due to male absence.) However, even this does not fundamentally challenge the male's role as formal (symbolic) household head. This is also reflected in the household internal division of labor and decisionmaking power. Women are not only responsible for the household chores, childcare, and agricultural tasks, but often also for the administration of the household money, whereas men are mainly responsible for income generation. The decision-making power depends upon the type of decision. While women usually take everyday decisions, decisions of greater consequence are reserved for men. "Family is a place where spatial and temporal boundaries are negotiated and migration often challenges existing power relations." 44 In Bajhangi Tole, gender relations have not been fundamentally renegotiated, although women gain decision-power within the household and the community under certain circumstances. Notwithstanding, since women are less exposed to their parents-in-law than in

\footnotetext{
${ }^{41}$ Government employment usually involves relocation to different workplaces within Nepal.

${ }^{42}$ Agergaard 1999b, 103.

${ }^{43}$ Ibid.

${ }^{44}$ Herzig and Thieme 2007, 1093-94; see also Kaspar 2004.
} 
their village of origin, they generally have greater leeway in their everyday lives. Differences regarding gender within the households can be largely explained by Nepalese values and norms. In Nepal, highcaste women remain under the strict male control of their father until marriage, of their husband after marriage, and of a son after the death of the husband. ${ }^{45}$ Nonetheless, these values and norms seem to be subtly challenged by the change of context through migration, as a decrease in the number of arranged marriages and slightly higher ages of marriage for both men and women in Bajhangi Tole indicate.

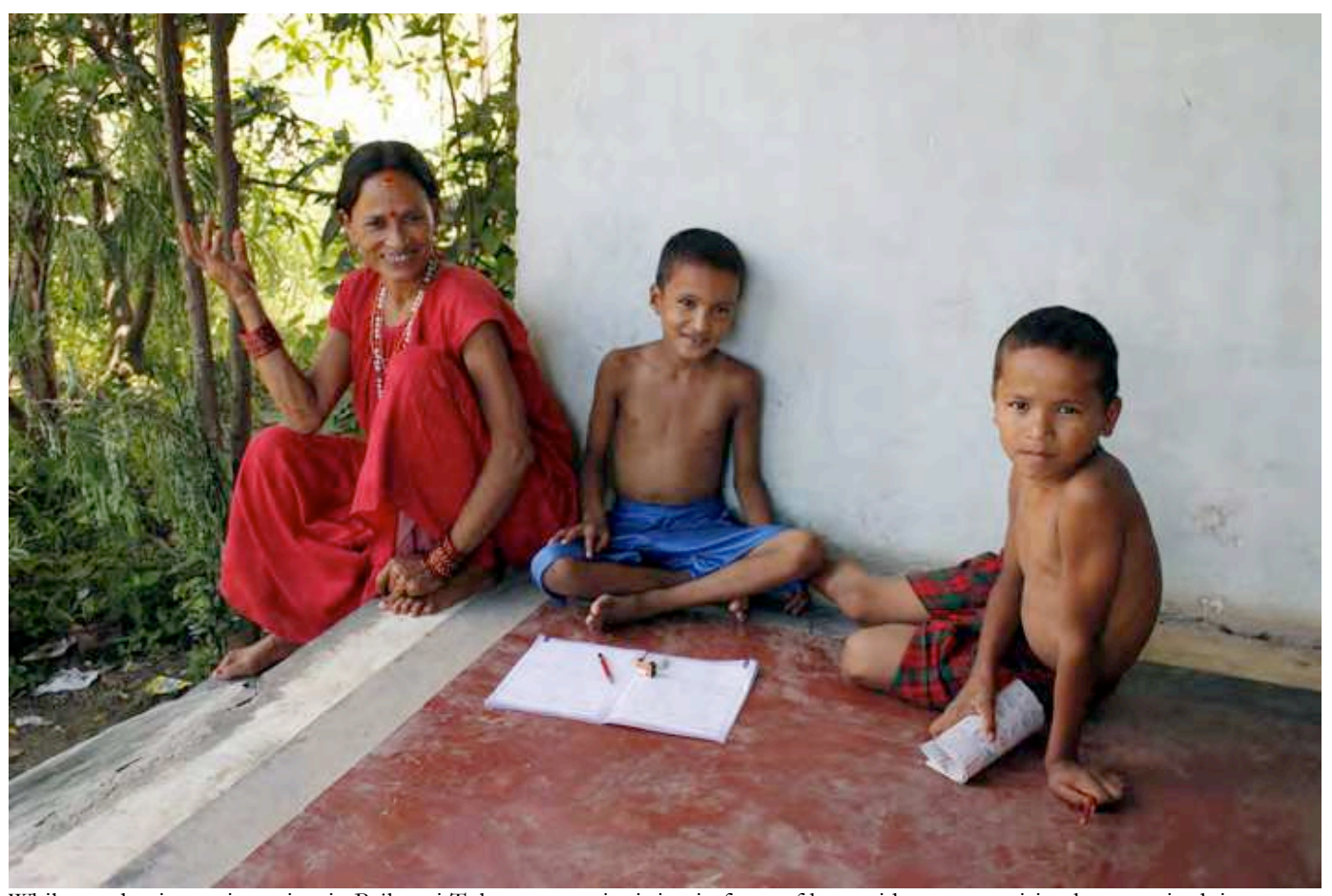

While conducting an interview in Bajhangi Tole a woman is sitting in front of her residence supervising her sons in doing homework. (Image: E. Poertner)

Internal migration also increases the access of women from the next generation to education, i.e. cultural capital. However, the access to the 'most valuable' form of cultural capital remains exclusive to men. From a community perspective, education qualifications, as a form of cultural capital, represent a means of accessing certain fields and are therefore held in high esteem in the local field of Bajhangi Tole. Institutionalized cultural capital is a 'barrier to entry' in the field of work, particularly government employment. The inhabitants of Bajhangi Tole consider education a pathway to upward social mobility. According to Bourdieu, education represents a seemingly reasonable mechanism to reproduce social classes ${ }^{46}$ by bestowing social agents with legitimate education qualifications: "The act of classification through education is always ... an act of ordination, an act of attribution like sanctification. It sets out social levels of distinction, definite class relations." ${ }^{47}$ Migration in particular - and, related to that, access to social fields at different places - seems to endow social agents with economic capital that can be transformed into educational qualifications.

\section{Internal migration strategies}

Bajhangi Tole is quite a young settlement. In-migration started about 18 years ago and has intensified in the last twelve years. In Dhangadhi municipality, communities like Bajhangi Tole also exist for people from other districts (Doti, Dadeldhura, Achham etc.). At the same time, further settlements of people from Bajhang can be found in other parts of Dhangadhi and in the rural area of Kailali.

\footnotetext{
45 Bista 1994, 63.

46 According to Bourdieu (1985, 725), social classes are "sets of agents who occupy similar positions and who, being placed in similar conditions and subjected to similar conditionings, have every likelihood of having similar dispositions and interests and therefore of producing similar practices and adopting similar stances."

47 Bourdieu 1998, 37.
} 
Generally, four types of migration trajectories from Bajhang to Dhangadhi were identified: (A) landless and flood-affected people who came through governmental resettlement programs (in the 196080s); (B) service sector jobholders (government officials and government school teachers) who could afford to buy land; (C) labor migrants in India who could afford to buy land with their savings; and (D) squatters occupying public land, which was later registered in their names. In the particular case of Bajhangi Tole, the service sector type (B) is the most common one. But there are also the resettlement and squatter types (A/D), households that have moved to Bajhangi Tole via the rural Terai. Moreover, a few households belonging to the category of successful labor migrants $(C)$ can be found in the settlement.

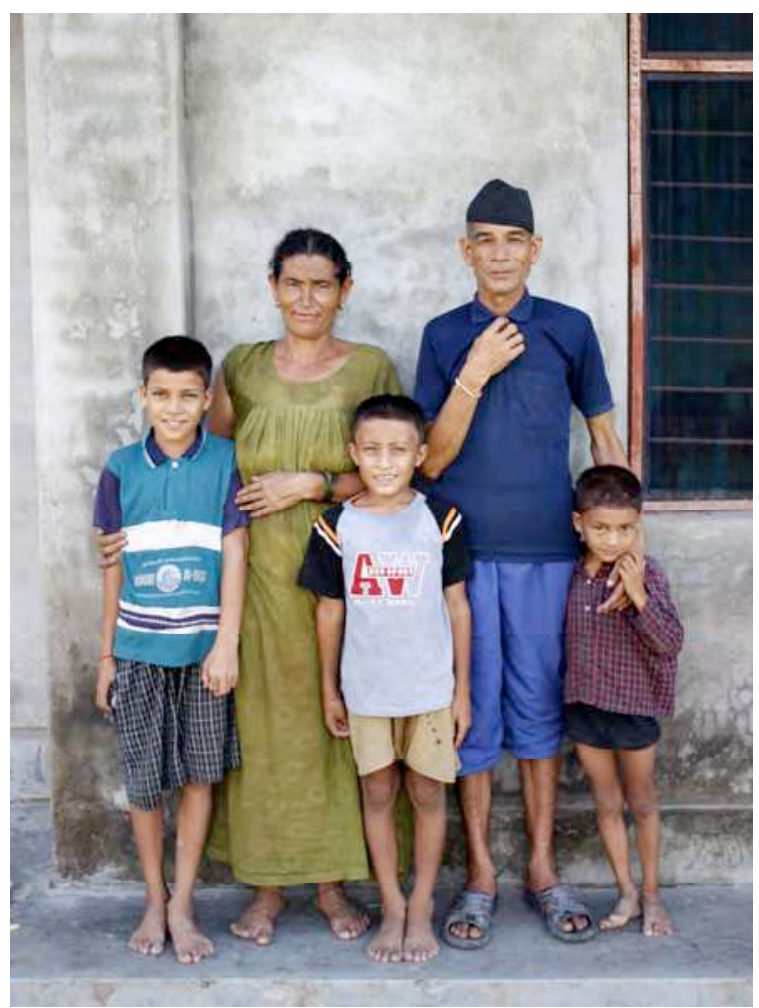

A migrant's household is gathering in front of their house for a photo shoot. The male household head was teaching in a primary school in Bajhang for 35 years before retirement. The wife decided to move to Shivanagar, because her son did not study well and did not pass the S.L.C. She wanted her grandchildren to have better education and better opportunities. (Image: E. Poertner)
There are two recognizable strategies by direct migrants: firstly, an economic strategy of improving the household's livelihood and securing its future through rural allowances and investment in education; secondly, a political strategy of coping with the threat in the hills during the Maoist conflict. Ultimately, the interplay of these different strategies was the crucial factor behind the internal migration of many households. The common reason for moving to the urban Terai for direct migrants (mostly teachers and government officials) is education, which is often mentioned together with facilities (such as hospitals). Today, education is virtually a symbol for the "bright future of the household" in Bajhang as well as in Bajhangi Tole. Since higher education institutions are not available in the hills, people migrate to places like Dhangadhi. The system of rural allowances is an economic incentive for government teachers to register in the Terai. In addition to a basic salary, government teachers (and other employees) receive allowances according to how 'remote' their workplace is from of the place where they live; the more 'remote' the district, the higher the rural allowances. The rural allowances for working in Bajhang while living in urban Terai amount to 75 percent of the basic salary. Thus, government employees can improve their salary when they relocate their household and register in Dhangadhi if they continue to work in 'remote' hill districts.

"A lot of Bajhangi teachers were attracted to Dhangadhi, because if they got land here, they could get rural allowances from schools here; they just had to show their land registration certificate of Dhangadhi to the related schools." (Man, 48 years old, Dhangadhi, 8 August 2009)

The precarious security situation in the hills during the Maoist conflict was a more political reason for direct internal migration. As representatives of the state, government employees were threatened by the Maoist forces in the hills and vulnerable to violence.

"Children were abducted in the hills [during the conflict]. Thus, to educate them, those parents who could afford to fled, bought land and settled here." (Man, 39 years old, Dhangadhi, 27 August 2009)

In contrast to direct migrants, indirect migrants moved to a rural destination in the Terai first. They migrated there for reasons related to agriculture and land access, namely due to landlessness, food scarcity or natural disasters, but more often to extend their economic activities from the hills to the Terai. This latter category resembles a type of migrants Shresta and Conway described in Chitwan as “... 'dispatched migrants', who were instigated by their families to move to the new area, seeking op- 
portunities to expand their economic activities and hold". ${ }^{48}$ Such indirect migrants who had already made one previous migration step to the rural Terai eventually moved to an urban settlement in Dhangadhi for education, facilities and centrality.

"Tugeda [a rural and remote part of Dhangadhi] was not easily accessible, as there is a river in between the central part of Dhangadhi and Jugeda. So, good schools ... were not accessible for the children in Jugeda and the schools in Jugeda were not good. As I wanted to give a good education to my children, I bought 1 kattha of land here in Shivanagar..." (Man, 53 years old, Dhangadhi, 21 August 2009)

However, we should mention one exceptional reason for indirect internal migration: one of the two Dalit households in the sample did not migrate to the rural Terai primarily for agricultural prospects; he left Bajhang because of the prevailing social discrimination in his village of origin. ${ }^{49}$

Social ties are the main reason for locating the household in a particular place. The vast majority of migrant household in Bajhangi Tole originates from a small region in Bajhang called Chhanna. Kinship and village networks established by a few pioneer settlers have channeled migration to Bajhangi Tole. These networks even advertise internal migration destinations and act as brokers for land.

"I came here through social ties. Some relatives and friends were already here. They showed me the land and the community here and I bought the land, built a house and settled here." (Man, 45 years old, Dhangadbi, 21 August 2009)

Hence, when one asks Bajhang people about social ties, they refer first and foremost to people from the respective village and region of origin within the district. Since the household location (in Dhangadhi) is not the same as their workplace in the hills, it is quite common for men in Bajhangi Tole to commute. But commuting is not a daily practice; men physically oscillate only a few times per year between the workplace and Dhangadhi. Hence, the members of government employee's households are involved in a set of migration practices (see fig. 1).

Conceptually, migration can be interpreted as a strategy by social agents to improve their social position in their place of origin. This strategy is enabled or constrained by how much capital of these social agents have, and at the same time represents an effort to transfer and/or increase a specific type of capital. Since economic capital generated through a well-paid job abroad can hardly be turned into a profitable capital investment in Bajhang itself, creating a household outpost in the (urban) Terai is a very effective and lucrative means of transferring capital: the household outpost itself is rewarded with symbolic capital, and at the same time, the children's education in Dhangadhi transfers economic capital into both cultural and symbolic capital. Hence, the reasons for the migration to an urban area are also related to how capital in the social field is valued in the home village. At the same time, economic capital is augmented by rural allowances. The motives for migration are often 'place attributes' - the presence or lack of facilities, security, fertile land, etc. Economic and social capital is critical for the access to new places such as Bajhangi Tole. Economic capital is a prerequisite for purchasing land, building a house and financing a private school education for one's children. A government job in the hills seems to increase the likelihood that this economic 'requirement' for participation can be met.

'It's for those who have money. The government employees and teachers have money, Rs. 500,000 to 700,000. They don't have to spend much money there in hills. So, I think that they also have to make a place in Dhangadhi." (Participant in the focus group discussion, Dhangadhi, 28 August 2009)

Social capital provides the social agent with access to information that allows him to enter the field at the destination. It thus tends to channel migration from a relatively small region of origin to certain locations, as has already been underlined in the case of international labor migration. ${ }^{50}$ In the case of government jobs, social networks also provide information about government projects and conditions for access - and this can open up new opportunities. In the case of resettlement, government officials knew about the projects (social fields) and about the terms and conditions for applications (the specific 'rules of the game'), which they were then able to capitalize on.

48 Shrestha and Conway 1985, 69-70.

${ }^{49}$ Already Dahal et al. stated that "the caste system of the hill people seems to have considerably relaxed in the Terai, although it continues to remain rigid in the hills" (Dahal, Rai, and Manzardo 1977, 128).

50 See Bruslé 2008; Müller-Böker 2003; Thieme 2006. 
"When I was working in Bajhang, I got the information about the resettlement program in the Terai. It was also for those, whose land was flooded. So, I applied for it and got 1.5 bigha ${ }^{51}$ of land here in Jugeda." (Man, 53 years old, Dhangadhi, 21 August 2009)

In contrast, Dalits often lack the necessary social and economic capital and therefore remain largely excluded from the field of Bajhangi Tole, which is predominantly "cultivated" by members of high castes and their social network.

\section{Linkages to international labor migration to India}

International labor migration to India is practiced by most of the households in the source district of Bajhang. ${ }^{52}$ A connection between this international labor migration and internal movements to the Terai can therefore be assumed. However, households that pursue a livelihood strategy of labor migration are quite rare in Bajhangi Tole due to the high proportion of teachers and government officials. There are nonetheless a few cases, and they indicate that successful international labor migrants effectively relocate their households in the Terai. This supports the linkage between international labor migration and internal migration suggested in the literature. A closer examination also unveiled that most of the households actually have linkages to international labor migration to India. However, these linkages only become visible if we do not just look at the households that settle in Bajhangi Tole, but also consider their broader family relationships.

The majority of households in Shivanagar have both close and distant relatives who currently work in India. The high number of relatives practicing labor migration to India (more than one per household in average) indicates how important this practice is for high-caste Hindus in Bajhang even today. In Bajhang, the lack of employment opportunities is the most common reason for international labor migration along with low agricultural production and the resulting food shortages. The fact that the households in Bajhangi Tole have adopted a different livelihood strategy than their close relatives suggests that often only one part of the extended family can avoid labor migration to India through education and salaried employment.

"My younger brother went to India four years ago. And my older brother went there 24 years ago. Now, they are together working as watchmen in Bangalore. They went there to get food. Both of them have taken their families with them. Their children are studying there. My older brother took bis family after four years working in Bangalore. That's already 20 years ago." (Man, 40 years old, Dhangadhi, 23 August 2009)

A historical perspective moreover revealed that labor migration to India was widespread in the father's and grandfather's generations of households in Bajhangi Tole. Interestingly, this 'background' of labor migration provided many households with a basis to improve their livelihoods and ultimately enabled them to migrate internally. In these cases, ancestors used to migrate to India for labor and sent remittances that were used for living expenses, but in addition they invested in land, status symbols and their sons' education.

"My father went to India for 40 to 45 years. He worked as a timber contractor in Nainital District. He got the job there because other people from Bajhang were already working there. My education [a Bachelor's degree in Kathmandu] was financed through money earned in India." (Man, 57 years old, Dhangadhi, 27 August 2009)

The resulting cultural capital enabled the son to find a government job, which, in turn, led to the discontinuation of labor migration to India. Concordantly, Agergaard found that employment as a civil servant can be seen as an alternative strategy to labor migration, but is only open to educated people with the necessary social relations. ${ }^{53}$ Labor migration to foreign places also contributes to the development of a 'sense of education' as Bista pointed out: "Nepalis who had been to India, or even further, were impressed by the contribution of education to modernization and were ready to support changes in the education system. It was mainly the upper caste people who pushed for education expansion." 54

\footnotetext{
51 bigha $=20$ kattha $=0.678$ ha.

52 Cameron 1998; Müller-Böker 2003; Müller-Böker and Thieme 2007; Pfaff-Czarnecka 1989, 2001; Shahi 2005.

53 Agergaard 1999b, 104.

${ }^{54}$ Bista 1994, 130.
} 
Table 1: Intergenerational migration strategies

\begin{tabular}{llll}
\hline & Generation 1 (ancestors) & Generation 2 (active generation) & Generation 3 (children) \\
\hline Destination & India & Terai & Kathmandu \\
\hline Reason & Low-skilled labor & Education, security, agriculture & Education, high-skilled labor \\
\hline Duration & Seasonally, temporary & Semi-permanent & Semi-permanent \\
\hline Source: Interviews, Dhangadhi, August 2009) & &
\end{tabular}

Participants of the focus group discussion estimated that about 50-80 percent of all households of government employees in Bajhangi Tole have an ancestral background of labor migration to India. This furthermore means that, in many cases, the economic and/or cultural capital of settlers originates from an ancestor's labor migration to India. These results indicate that households adopt different migration strategies in different generations for specific reasons (see table 1).

\section{Social networks, rootedness and multi-locality}

An analysis of the kinship relations of the households in Bajhangi Tole to different locations confirmed, on the one hand, the social importance of the place of origin in Bajhang and, on the other hand, it revealed a distinct multi-local pattern of spatial linkages of the households.

In Bajhangi Tole, the strong aphno manchbe $e^{55}$ (kin and villager) ties - manifested in practices of mutual support and communal activities - are to a certain degree institutionalized in Surma Devi Samas, a local organization of immigrants from Bajhang in Dhangadhi. Surma Devi Samas provides services and security to the Bajhangi community in Dhangadhi and organizes rituals and celebrations to perpetuate and consolidate Bajhangi networks. Furthermore, it institutionalizes and encircles the community through the publishing of the phone directory listing all Bajhangi households in Dhangadhi according to their 'places of housing' (i.e. the municipality ward) and their 'places of origin' (i.e. their villages of origin in Bajhang). Households thereby receive a spatial reference that already includes two or more places. As Dahal et al. acknowledged, migration to the Terai changes the environment for hill migrants drastically. ${ }^{56}$ To preserve the structures of their social world, hill migrants often try to live among migrants from the same village of origin. Dense social networks of the community in Bajhangi Tole and the Surma Devi Samas reflect this aspiration to preserve. For the Bajhangi people in Dhangadhi, Surma Devi Samas represents an important means of reproducing social and symbolic capital linked to their place of origin.

Most households in Bajhangi Tole still have strong ties to Bajhang - or more precisely to the village of origin and the ancestral home. As the vast majority of households have close relatives living in Bajhang, usually their parents and/or brothers with their families, the social and emotional connection to Bajhang stays close. It is maintained through visiting practices and means of communication. In general, the husband visits Bajhang much more often than his wife and children, the explanation being that the husband has stronger ties to his ghar, transport costs are relatively high, ${ }^{57}$ women have duties in the household, and the 17-to-18-hour journey to Bajhang is strenuous and rather risky. Men usually visit Bajhang a few times a year, mostly for festive occasions (e.g. Dashain, Tihar), worship (puja), marriages, in emergencies, or (more rarely) to help out in agriculture. In households where the husband still works as a teacher in the village of origin (or close by) visiting practices are evidently different. However, even in these cases, women and children do not visit Bajhang more often than those in other households. Husbands working in the hills visit Bajhang mainly during vacations. The sons who are studying in Kathmandu also visit Bajhangi Tole during their vacations. Kin from Bajhang visit Shivanagar quite often - maybe even slightly more than the other way round.

"The parents and the younger brothers come to Shivanagar often during the winter months - for visits, treatment, and services." (Man, 40 years old, Dhangadhi, 23 August 2009)

\footnotetext{
55 An important social institution in Nepal is aphno manchbe (literally 'one's own people'), which is a manifestation of collectivism and a natural form of social organization (Bista 1994, 4). Aphno manchbe stands for the own secure inner circle of social associates, which very few Nepalis are willing to leave. "Nepalis will never be willing to knock down existing circles of identity unless they have the option of crossing the line from one to another, and this will not be possible for the vast majority of the people except for those in the middle classes in urban areas with a modern education." (Bista 1994, 99).

${ }^{56}$ Dahal, Rai, and Manzardo 1977, 43.

57 The bus fares between Dhangadhi and the district headquarters of Bajhang, Chainpur, cost about Rs. 700 in 2009 (one-way).
} 
The pleasant lowland climate in winter and the spare time people have during agricultural off-season are arguably further reasons for this practice. New means of communication, namely mobile phones and CDMA ${ }^{58}$ Sky phones, are increasingly used to stay in touch with relatives and friends elsewhere without meeting physically. Internal remittances between Bajhang and Bajhangi Tole are quite rare. However, households hosting children from the extended family during their studies in Dhangadhi sometimes receive a form of alimony from their relatives in Bajhang.

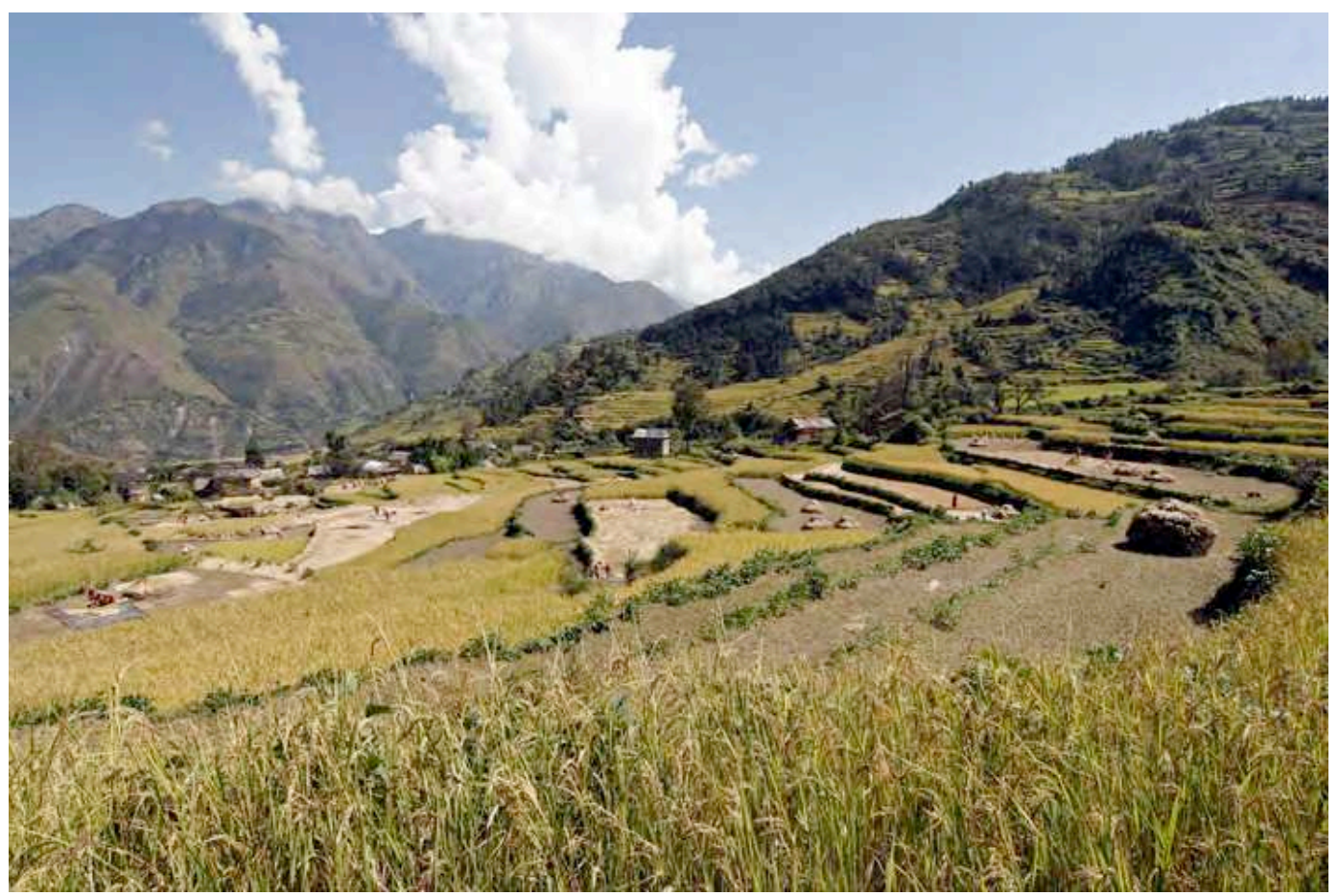

The place of origin: a spectacular scenery of the Chhanna region in Bajhang district, located on the northern slopes of Khaptad National Park in the hill zone of far western Nepal. (Image: M. Junginger)

A gender perspective reveals that women's social networks are considerably less dense than men's. Generally, internal migration seems to be a bit of a double-edged sword for women as far as their social networks and decision-making power are concerned. Women become increasingly uprooted from their traditional women networks through this internal movement. First of all, women lose their social network through internal migration after marriage from the maiti (paternal home of a married woman) to the ghar. In their husbands' village, everyday life and labor once again becomes embedded in women networks. However, their relocation in the lowland severs these ties, which are strongly linked to traditional agricultural labor-pooling agreements in Bajhang. Furthermore, Nepal's patriarchal societal organization (still) leaves little room for women to define their own needs. ${ }^{59}$

The generation of household members that took the migration step to the lowland undoubtedly perceives Bajhang and the village of origin as their home. Over a person's lifecycle, the place requirements change. During a person's working life, employment opportunities are crucial; after retirement, low living costs, a social network, and amenities for the old aged become increasingly important.

'It's not fixed that we will stay here. Since [in Bajhang] we have a bouse, land, and brothers, and the weather is good too. The only thing missing is transport - we would have to carry things. I have thought about it. It could happen some day." (Man, 45 years old, Dhangadhi, 21 August 2009)

Rootedness can thus also signify that some of the residents will one day return to their home place. Some respondents argued that if the infrastructure and facilities in Bajhang became more developed, they could imagine returning and out-migration from Bajhang would largely cease. However, when asked whether they actually intended to return to Bajhang, most of the informants answered that they

58 CDMA stands for 'Code Division Multiple Access', which is a method used by various radio communication and mobile phone technologies to enable many users to communicate on one channel (Viterbi 1995).

${ }^{59}$ Cf. Kaspar 2004, 136. 
do not expect to go back there. Nonetheless, some of them are considering returning to Bajhang after they retire for financial reasons.

According to Conway, migration leads to an exchange of homes, with one being left behind. ${ }^{60} \mathrm{~A}$ new 'home away from home' 61 is imbued with meaning and identity through the time spent there and new social and spatial interaction. However, ties to the previous home - often referred to as the 'real home' - are usually sustained and fuel - together with 'feelings of alienation' towards the new environment - the retention of a 'return mythology'. ${ }^{62}$ The subsequent generation, which has grown up in Dhangadhi, has a different sense of place, a different rootedness to the ancestral home and the village of origin than their parents' generation. A certain de-rooting of the second or even the third generation supposedly reduces the attachment to the land and house in the hills, if they do not spend a substantial part of their life there. "For those with limited residency, superficial, partial and personal senses of place ... [are] contrasted by the depth of an ancestral sense of place through being raised there and of a cultural sense of place through generations on the land and spiritual connections to it". ${ }^{63}$

Fig. 2: Spatial network of the households in Bajhangi Tole

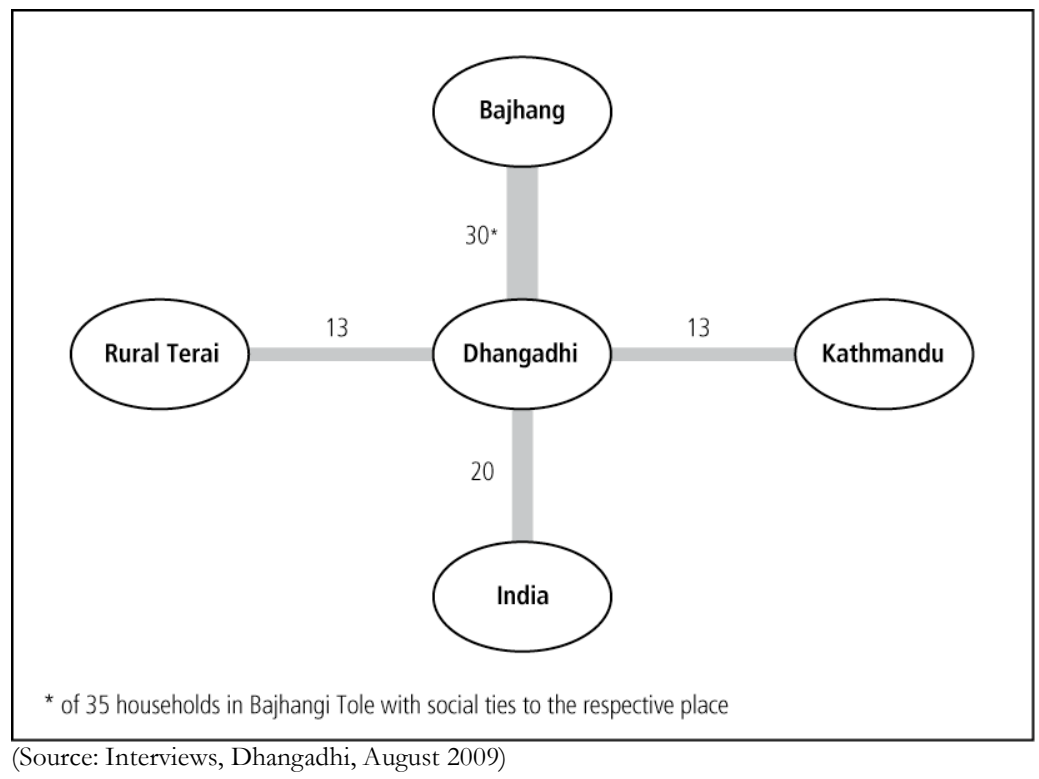

Apart from the strong ties to Bajhang, which are manifested in social relations, landholdings, visiting and communication practices, the households in Bajhangi Tole also have noteworthy social connections to India, Kathmandu, and to other parts of the far western Terai (see fig. 2). The high incidence of labor migration to India among kinship as well as the proximity to India explains the ties to the neighboring country. The significance of Kathmandu arises primarily from the practice of families sending their sons there to study. Indirect migrants previously lived in Kanchanpur and (rural) Kailali, and often still have relatives living in these places. Thus, migratory practices over generations extend the social, and with it the spatial, network of kinship from Bajhang to India, Dhangadhi, Kathmandu and a series of other places. As long as the social ties to these places remain strong, an intergenerational network including different localities inside and outside the country will develop; this could be called a 'multi-local' network.

A similar pattern of such 'intergenerational multi-locality' has already been described by Subedi in eastern Nepal. ${ }^{64}$ In this case, the economic capital arising from labor migration to India was invested by successive generations in land in the hills, in household residences in the Terai outlets, and even in the larger Terai cities or in Kathmandu. However, the internal household relocations were not related to government employment and not (primarily) aimed at education. Notwithstanding this, the similar

${ }^{60}$ Conway 2005.

${ }_{61}$ Vertovec 1999, 450.

62 Conway 2005, 274.

${ }^{63}$ Hay 1998, 25.

${ }^{64}$ Subedi 1993. 
pattern indicates that 'intergenerational multi-local' networks can arise from successive and reversible migration practices. The addition of new residences in different locations does not seem, in the case of Bajhangi Tole, to be like the case of eastern Nepal described above; it is not an 'adventurous' move, but instead a strategic one that improves a family's livelihood perspectives and its symbolic capital too. However, the 'historical depth' of such spatial kinship networks seems in both cases to be considerable. Even after generations, the ancestral home and inherited land is perceived as a form of insurance for times of emergency and a symbol of the potential reversibility of the migration chain. In fact, the reversible character of migration actually carries two connotations: a de-rooting from the place of origin, but also a re-rooting, for instance in the case of male household heads who plan to return to Bajhang after retiring.

\section{Conclusion}

The article contributes to the understanding of internal migration practices in Nepal. It has explored the case of high-caste government employees migrating to an emerging Terai city for their children's education and for security during the conflict. It provides additional insights to studies conducted at international migration destinations in India ${ }^{65}$ and at the place of origin, Bajhang ${ }^{66}$. It sheds light on the practices and strategies of a thus far neglected category of internal migrants: government employees, a privileged and respected, but also politically controversial stratum of Nepalese society. As Bourdieu emphasized, social space tends to manifest itself in geographical space. ${ }^{67}$ The social status of the community is reflected in the central location of the settlement in Dhangadhi, the solid houses, and the relatively high living standard - but also in the intra-communal differences in housing and the size and location of landholdings. The majority of households rely on men's income from government employment. Since many of them are employed in the hills, their job involves periods of absence from their residence in Dhangadhi. Ostensibly, the government employees have relocated their households to a central urban settlement to further their children's education. On closer examination, additional or even pivotal reasons for many of them migrating internally have been the benefits they derive from allowance regulations and, in the past decade, escaping from the armed conflict. Others did not migrate directly to the urban destination but to rural parts of the Terai for agricultural prospects first. Despite the household's relocation to Dhangadhi, the ancestral home and land in the hills are rarely abandoned, and strong social ties to the place of origin are maintained. Social and emotional attachment to the ancestral home and the village of origin are sustained through mutual visiting practices and telecommunications. This strong identification with the place of origin is likely to remain, since the migrant community consists to a large degree of households from a relatively small region of origin; Bajhangi networks and culture are institutionalized and perpetuated through a local organization.

The case study shows that gender roles are not fundamentally challenged by internal rural-to-urban migration. In most case, women's decision-making power is still restricted to everyday householdrelated decisions. According to the evidence, social relations such as aphno manchbe (kin and villager ties) and caste affiliation play a crucial role in channeling migration to a specific location and promoting a specific social group. We have furthermore highlighted that internal migration can be linked to international labor migration of former generations. The findings thus support Skeldon's claim that internal and international migration are often interlinked. ${ }^{68}$ The assumption by different authors ${ }^{69}$ that international labor migration can lead to a relocation of the household to the Terai is not fundamentally challenged. However, the historical depth of the study has disclosed that the same household will adopt different livelihood strategies related to migration over the generations: from seasonal or temporary labor migration to India, to civil service in the hills, and ultimately to high school education and employment in the private or public sector in the Terai cities or Kathmandu. Therefore, we suggest considering the possibility of a linkage between international and internal migration beyond the close household level and over more than one generation. Such an approach can reveal the emergence of multi-local networks of households where migration is practiced over generations and is coupled with a strong rootedness to the place of origin.

\footnotetext{
65 Thieme 2006.

${ }^{66}$ Müller-Böker 2003; Pfaff-Czarnecka 2001; Shahi 2005.

${ }^{67}$ Bourdieu 1991.

${ }^{68}$ Skeldon 2006.

${ }^{69}$ Bruslé 2008; Pfaff-Czarnecka 2001; Shahi 2005; Thieme 2006; Thieme, Müller-Böker, and Backhaus Forthcoming.
} 
Further research on rural-to-urban (and vice versa) migration seems necessary in order to understand the complex motives and strategies of different groups of internal migrants and how they relate to labor, education, and economic development at household level. Moreover, in-depth studies about the impact of household relocations on women and particularly their social networks appear crucial if we wish to understand intra-household power dynamics related to migration. Finally, an analysis of destinations and social networks of different population strata, different caste and ethnic groups could unveil their specific migration strategies and migration patterns over generations, similarly to this study or that of Subedi. ${ }^{70}$ This will enable more concerted development efforts in a country of high population mobility such as Nepal, since it will help to understand this mobility as an integral part of people's lives.

\section{Acknowledgements}

This study was conducted within the framework of the Thematic Node 1 ('Institutions, Livelihoods, Conflicts') of the Swiss National Centre of Competence in Research (NCCR) North-South: Research Partnerships for Mitigating Syndromes of Global Change, and the ProDoc research module 'Negotiating rural development in South Asia's periphery'. The NCCR North-South is co-funded by the Swiss National Science Foundation (SNSF) and the Swiss Agency for Development and Cooperation (SDC). Further funding was provided by the ProDoc (SNSF) project 'Negotiating rural development in South Asia's periphery'. A debt of gratitude is owed to Kiran Maharjan, who accompanied both Ephraim Poertner and Mathias Junginger on their field research trip and provided invaluable translation, explanations and scientific support. We are furthermore indebted to our colleagues Rony Emmenegger and Susan Thieme for their fruitful feedback and suggestions in the process of writing this article.

\section{References}

Adhikari, Jagannath, and Ganesh Gurung. 2009. Migration, Security and Livelihoods: A Case of Migration between Nepal and India. Kathmandu: NIDS, NCCR North-South.

Agergaard, Jytte. 1999a. "Settlement and Changing Land Use in the Chitwan District of Nepal." Geografisk. Tidsskrift, Danish Journal of Geography, no. 1 (Special Issue): 11-19.

1999b. "The Household as a Unit of Analysis: Reflections from Migration Research in Nepal." Geografisk Tidsskrift, Danish Journal of Geography 99: 101-111.

Bhattarai-Ghimire, A., and B. R. Upreti. 2008. "Conflict Induced Displacement: An Emerging Phenomenon of Internal Migration in Nepal". In Nepal: Transition to Transformation, edited by K. N. Pyakuryal, B. R. Upreti and S. R. Sharma. Kathmandu: HNRSC, NCCR North-South.

Bhattrai, Raju. 2007. "Open Borders, Closed Citizenships: Nepali Labor Migrants in Delhi." Paper presented at the Panel 5: International Migration, Citizenship, Identities and Cultures, Institute of Social Studies, The Netherlands 2007.

Bista, Dor Bahadur. 1994. Fatalism and Development. Nepal's Struggle for Modernization. 6th ed. Hyderabad: Orient Longman.

Bohra, Pratikshya, and Douglas S. Massey. 2009. "Processes of Internal and International Migration from Chitwan, Nepal." International Migration Review 43, no. 3: 621-651.

Bourdieu, Pierre. 1977. Outline of a Theory of Practice. Cambridge: Cambridge University Press.

- 1991. "Physischer, sozialer und angeeigneter physischer Raum". In Stadt-Räume. Die Zukunft des Städtischen, edited by M. Wentz. Frankfurter Beiträge, Bd. 2., Frankfurt/Main, New York. 1998. Praktische Vernunft. Zur Theorie des Handelns. Frankfurt/Main: Suhrkamp.

Bourdieu, Pierre, and Loïc J. D. Wacquant. 1992. An Invitation to Reflexive Sociology. Cambridge: Polity Press.

Brettell, Caroline B., and James F. Hollifield. 2007. "Introduction: Migration Theory". In Migration Theory. Talking Across Disciplines, edited by C. B. Brettell. London: Routledge.

Bruslé, Tristan. 2008. "Choosing a Destination and Work." Mountain Research and Development 28, no. 3: 240-247.

Cameron, Mary M. 1998. On the Edge of the Auspicious. Gender and Caste in Nepal. Urbana and Chicago: University of Illinois Press.

Conway, Dennis. 2005. "Transnationalism and Return: 'Home' as an Enduring Fixture and 'Anchor"'. In The Experience of Return Migration. Caribbean Perspectives, edited by R. B. Potter, D. Conway and J. Philips. Aldershot: Ashgate.

\footnotetext{
70 Subedi 1993.
} 
Dahal, Dilli Ram, Navin Kumar Rai, and Andrew E. Manzardo. 1977. Land and Migration in Far-Western Nepal. Kathmandu: Institute of Nepal and Asian Studies, Tribhuvan University.

De Haan, Arjan, and Ben Rogaly. 2002. "Introduction: Migrant Workers and Their Role in Rural Change." Journal of Development Studies 38, no. 5: 1-14.

De Haan, Leo, and Annelies Zoomers. 2005. "Exploring the Frontier of Livelihoods Research." Development and Change 36, no. 1: 27-47.

Dhangadhi Municipality. 2008. "Poverty Profile of Dhangadhi Municipality 2008".

Dörfler, T., O. Graefe, and D. Müller-Mahn. 2003. "Habitus und Feld. Anregungen für eine Neuorientierung der geographischen Entwicklungsforschung auf der Grundlage von Bourdieus "Theorie der Praxis"." Geographica Helvetica 58, no. 1: 11-23.

Ghimire, Anita, Bishnu Raj Upreti, and Subash Pokharel. 2010. "Livelihood Strategies of Internally Displaced People in Western Nepal: Some Observations". In Livelihood Insecurity and Social Conflict in Nepal, edited by B. R. Upreti and U. Müller-Böker. Kathmandu: South Asia Regional Coordination Office, Swiss National Centre for Competence in Research (NCCR) North-South.

Grandin, B. E. 1988. Wealth Ranking in Smallholder Communities: A Field Manual. Rugby, UK: Intermediate Technology Publications.

Graner, Elvira. 2001. "Labor Markets and Migration in Nepal: The Case of Workers in Kathmandu Valley Carpet Manufactories." Mountain Research and Development 21, no. 3: 253-259.

Hay, Robert. 1998. "Sense of Place in Developmental Context." Journal of Environmental Psychology 18, no. 1: 5-29.

Herzig, Pascale, and Susan Thieme. 2007. "How Geography Matters. Neglected Dimensions in Contemporary Migration Research." Asiatische Studien/Etudes asiatiques, no. LXI 4/2007: 10771112.

HMG. 1998. "Dhangadhi. Nepal 1:25’000, Sheet No. 2880 07A". edited by Survey Department. Kathmandu: His Majesty's Government of Nepal (HMG).

Kansakar, Vidya Bir Singh. 2003. "International Migration and Citizenship in Nepal". In Population Monograph Nepal, edited by CBS (Central Bureau of Statistics). Kathmandu: CBS.

Kaspar, Heidi. 2004. Impacts of International Labour Migration on Gender Relations. A Case Study of Kalabang, Nepal. Zurich: Master's Thesis, University of Zurich.

KC, Bal Kumar. 2003. "Internal Migration in Nepal". In Population Monograph Nepal, edited by CBS (Central Bureau of Statistics). Kathmandu: CBS.

Kollmair, M., S. Manandhar, B. Subedi, and S. Thieme. 2006. "New Figures for Old Stories: Migration and Remittances in Nepal." Migration Letters 3, no. 2: 151-160.

Luitel, Seema. 2006. "Migrants Marginalization and Uses of Social Capital from a Gender Perspective: A Case Study from Tinthana VDC, Kathmandu, Nepal." Master's Thesis, School of Environment, Resouces and Development, Asian Institute of Technology (AIT), Bangkok.

Massey, Douglas S., Joaquin Arango, Graeme Hugo, Ali Kouaouci, Adela Pellegrino, and J. Edward Taylor. 1994. "An Evaluation of International Migration Theory: The North American Case." Population and Development Review 20, no. 4: 699-751.

Müller-Böker, Ulrike. 1997. "Tharus and Pahariyas in Chitawan: Observations on the Multi-Ethnic Constellation in Southern Nepal". In Perspectives on History and Change in the Karakorum, Hindukush, and Himalaya, edited by I. Stellrecht and M. Winiger. Köln: Köppe. 1999. The Chitawan Tharus in Southern Nepal. An Ethnoecological Approach. Stuttgart: Steiner. 2000. "State Intervention in Chitwan. On the Historical Development of a Region in Southern Nepal." Studies in Nepali History and Society 5, no. 2: 173-200.

2001. "Pahariya-Migration to the Tharu's Settlement Area of the Inner Terai (Chitawan)". In Aspects of Migration and Mobility in Nepal, edited by v. d. Heide, Susan and T. Hoffman. Kathmandu: Ratna Pustak Bhandar.

2003. "Livelihood Strategies in the Buffer Zone of the Khaptad National Park (Far West Nepal)". In Translating Development: The Case of Nepal, edited by M. Domroes. Delhi: Social Science Press.

Müller-Böker, Ulrike, and Susan Thieme. 2007. "Livelihood Strategies in a Marginal Area of Nepal (Far West Nepal), with an Emphasis on Labour Migration to India". In Issues in Geographical Marginality: Papers presented during the Meetings of the Commission on Evolving Issues of Geographical Marginality in the Early 21 st Century World, edited by G. Jones. Grahamstown.

Pfaff-Czarnecka, Joanna. 1989. Macht und rituelle Reinheit. Hinduistisches Kastenwesen und ethnische Beziebungen im Entwicklungsprozess Nepals. Grüsch: Rüegger. 
1996. "Die Wächter der Metropole. Nepalische Migranten in Bangalore, Südindien." Mosquito, no. 4: 14-15.

2001. Vom Untertan zum Bürger? Eine Ethnopolitologie der Entwicklung in Nepal-Himalaya. Zürich: Habilitationsschrift.

Schwingel, Markus. 1995. Bourdieu zur Einfübrung. Hamburg: Junius-Verlag.

Seddon, David, Jagannath Adhikari, and Ganesh Gurung. 2002. "Foreign Labor Migration and the Remittance Economy of Nepal." Critical Asian Studies 34, no. 1: 19 - 40.

Shahi, Meen Bahadur. 2005. "International Labour Migration from Bajhang to India: A Case Study of Lamatola VDC, Bajhang District, Nepal." Master's Thesis, Central Department of Geography, Tribhuvan University, Kathmandu.

Sharma, Jeevan R. 2007. "Labour Migration, Pathology and Livelihoods: The case of Migration from Nepal to India." Paper presented at the Panel 2: The migration-development nexus, International migration, multi-local livelihoods and human security: Perspectives from Europe, Asia and Africa, Institute of Social Studies, The Netherlands 2007.

Sharma, Pitamber. 2003. "Urbanization and Development". In Population Monograph Nepal, edited by CBS (Central Bureau of Statistics). Kathmandu: CBS.

Shrestha, Bijaya. 2008. "Contribution of Foreign Employment and Remittances to Nepalese Economy". In Economic Review, edited by T. Pangeni, N. B. Thapa, S. D. Kafle and B. Pant.

Shrestha, Nanda, and Dennis Conway. 1985. "Issues in Population Pressure, Land Resettlement, and Development: The Case of Nepal." Studies in Comparative International Development (SCID) 20, no. 1: 55-82.

Shrestha, Nanda R. 1989. "Frontier Settlement and Landlessness among Hill Migrants in Nepal Tarai." Annals of the Association of American Geographers 79, no. 3: 370-389.

1990. Landlessnesss and Migration in Nepal. Boulder, San Francisco, London: Westview Press.

Skeldon, Ronald. 2006. "Interlinkages between Internal and International Migration and Development in the Asian Region." Population, Space and Place 12, no. 1: 15-30.

Subedi, Bhim Prasad. 1991. "International Migration in Nepal. Towards an Analytical Framework." Contributions to Nepalese studies 18, no. 1: 83-102.

1993. Continuity and Change in Population Movement: From Inside a Rural Nepali Community. Ann Arbor: UMI.

Tamang, Ritendra. 2009. "Internally Displaced Persons in Nepal: Neglected and Vulnerable." Asian Social Science 5, no. 6: 3-11.

Thapa, Poonam. 1989. Socioeconomic Change and Rural Migration in Nepal. Individual and Household Relations. Ann Arbor: University Microfilms.

Thieme, Susan. 2006. Social Networks and Migration: Far West Nepalese Labour Migrants in Delhi. Münster: LIT.

2008. "Sustaining Livelihoods in Multi-local Settings: Possible Theoretical Linkages Between Transnational Migration and Livelihood Studies." Mobilities 3, no. 1: 51-71.

Thieme, Susan, Raju Bhattrai, Ganesh Gurung, Michael Kollmair, Siddhi Manandhar, and Ulrike Müller-Böker. 2005. "Addressing the Needs of Nepalese Migrant Workers in Nepal and in Delhi, India." Mountain Research and Development 25, no. 2: 109-114.

Thieme, Susan, Ulrike Müller-Böker, and Norman Backhaus. Forthcoming. "Glimpses of Women's Livelihoods in a Transnational Social Space: Labour Migration from Far West Nepal to Delhi, India". In Print, Department of Geography, University of Zurich.

Thrift, Nigel. 1996. Spatial Formations. London: Sage.

Timalsina, Krishna Prasad. 2007. "Rural Urban Migration and Livelihood in the Informal Sector. A Study of Street Vendors of Kathmandu Metropolitan City, Nepal." Master's Thesis, Department of Geography, Norwegian University of Science and Technology (NTNU), Trondheim.

Upreti, B. C. 2002. The Marginal Migrants: A Study of Nepali Emigrants in India. Delhi: Kalinga Publications.

Vertovec, Steven. 1999. "Conceiving and Researching Transnationalism." Ethnic and Racial Studies 22: 447-462.

Viterbi, Andrew J. 1995. CDMA: Principles of Spread Spectrum Communication. Upper Saddle River, NJ: Prentice Hall PTR.

Wyss, Simone. 2003. Organisation and Finance of International Labour Migration. A Case Study of Sainik Basti, Western Nepal. Zurich: Master's Thesis, University of Zurich. 